\title{
THE SEDGWICKIAN QUEERNESS OF AN ANIME LESBIAN: READING REVOLUTIONARY GIRL UTENA
}

\author{
GiANCARLO CORNEJO \\ University of Southern California
}

\begin{abstract}
A tentative response to Eve Sedgwick's timely question "How to bring your kids up gay?" lies at the heart of Kunihiko Ikuhara's anime TV series Shoujo Kakumei Utena (1997). This article explores the affective sustenance that Revolutionary Girl Utena offers to some queer children and teens in the face of a somber heteronormative reality. The essay performs a close reading of episode seven, "Unfulfilled Juri", and focuses on one of the queer feminine characters that the show cultivates, the tragic (joyful) lesbian. Paradoxically, and fortunately, this anime lesbian is far from being an abject figure and, in fact, becomes a site for queer identifier projections and desires.

KEY WORDS: anime, lesbian, queer, Revolutionary Girl Utena.

La identidad queer de una anime lesbiana según Sedgwick: una lectura de Utena: la chica revolucionaria

La serie de anime de Kunihiko Ikuhara Shoujo Kakumei Utena (1997) ofrece una posible respuesta a la pregunta de Eve Sedgwick "How to bring your kids up gay?". Este artículo explora la dimensión afectiva que Utena: la chica revolucionaria ofrece a adolescentes queer frente a la sombría realidad heteronormativa. En el texto se lleva a cabo una lectura detallada del séptimo episodio, "Juri, la insatisfecha", mediante el análisis de uno de los personajes femeninos queer de la serie que da vida a una lesbiana trágica pero feliz. Paradójica y afortunadamente, este personaje no está construido como una figura abyecta y, de hecho, llega incluso a convertirse en un lugar de identificación de las proyecciones y deseos queer.
\end{abstract}

PALABRAS CLAVE: anime, lesbiana, queer, Utena: La chica revolucionaria.

"It's always open season on gay kids" (1991: 18) is a memorable sentence from Eve Kosofsky Sedgwick's powerful essay "How to Bring Your Kids Up Gay", a text that has rightfully become an essential part of the transnational canon of Queer Theory. In it, Sedgwick offers a close reading of psychological clinical practices and theories that construct and reify the effeminate boy as a "haunting abject" (20). In Sedgwick's account, the refusal to think critically on the violence against the effeminate boy would merely reaffirm the widespread "wish that gay people [should] not exist" (23; italics in the original). From the title of her essay, one can correctly assume that Sedgwick attempts to oppose this homophobic, widespread wish. Sedgwick acknowledges that "the number of persons or institutions by whom the existence of gay people is treated as a precious desideratum, a needed condition of life, is

Cornejo, Giancarlo (2021), "The Sedgwickian Queerness of an Anime Lesbian: Reading Revolutionary Girl Utena", Lectora, 27: 211-226. ISSN: 1136-5781 D.O.I.: 10.1344/Lectora2021.27.10, gcornejo@cinema.usc.edu

Recepció: 15 de desembre de 2020 - Acceptació: 21 d'abril de 2021 
small" (23), and precisely for that reason she invites her readers to join the community for which queerness is a "needed condition of life". Against a "Western fantasy of a world without any homosexuals in it" (25), Sedgwick dares to ask "how to bring your kids up gay" (18). One of the merits of the essay is that it dares to raise such a question, and in so doing it invites its readers to dwell on the question and challenges them to try to answer it.

I argue that Sedgwick's question has been insightfully addressed by a cultural object unfamiliar to most US-based queer theoretical accounts, Kunihiko Ikuhara's anime TV series Shoujo Kakumei Utena (1997). At a most visceral level, I dare to offer a queer theoretical reading of Revolutionary Girl Utena, because my own queer becoming is intimately related with my watching this anime TV series in my childhood in the late 1990s. In a few words, I cannot imagine being the kind of queer I am without having crossed paths with Utena. Going back to Sedgwick's account, the survival of the effeminate boy only takes place when a flight from narrow and normative versions of masculinity is made available. In Sedgwick's argument, when the effeminate boy cannot become a fugitive of normative masculinity, there are likely two intimately related outcomes: suicide, and the assassination of queerness in children via a paranoid indoctrination of heterosexual masculinity. Unlike that somber scenario, the sustenance that Revolutionary Girl Utena offers to some queer children and teens, like the effeminate boy I was, does not only lie in performing the role of shelter from normative masculinity, but in envisioning and actualizing many forms of queer female passions, joys, and sorrows. Revolutionary Girl Utena teaches many queer and trans kids that to escape from cisgender heterosexual masculinity is not only possible, but desirable.

Revolutionary Girl Utena offers a world in which queerness is a precious condition of life, and a requirement to dream of any revolution. The main protagonist of this 39-episode TV series is Utena Tenjou, a fourteen-year-old tomboy who dreams of reuniting with a prince that saved her from dying in her childhood. In the path to reconnecting with her prince, Utena "transfers to Ohtori Private Academy, a strange and secluded school governed by the mysterious Rule of the Rose Seal. At Ohtori, duels are held between students. To the victor goes the Rose Bride, a shy girl named Anthy, and the Sword of Dios, which holds the power to revolutionize the world" (Saito 2020: 2). The TV anime explicitly frames the bond between Utena and Anthy Himemiya, female student at the same school, as an engagement. In the most relevant theoretical take on Utena, "Metamorphosis of the Japanese Girl: The Girl, The Hyper-Girl, and the Battling Beauty" (2006), Mari Kotani focuses on the queer pairing of Utena and Anthy. According to Kotani, they take up 
roles [that] are, in a sense, stereotypical — prince and princess [...]. Yet the prince [Utena] is, of course, a girl in boy's attire - and pink at that. And princess [Anthy] is just a bit too obedient. Revolutionary Girl Utena thus makes a mockery of conventional gender roles and narratives. [...] Ultimately, from episode to episode, it is this queer couple that survives the series of duels - the mock prince and slave princess. (165)

Utena, whom Kotani calls a "transvestite prince" (165), departs from normative gender roles. She refuses to wear a female school uniform and opts to use the masculine one, openly avowing her desire to mimic her own prince. In addition, Utena uses a first-person male pronoun (boku). In Utena's mobilization of this pronoun, we can see an articulation of a proto-gender non-binary identity location. Given this premise, it shouldn't be a surprise that many queer kids, including some Sedgwickian effeminate boys, treasure(d) and resonate(d) with the queerness of Utena.

My premise is simple: everything about Revolutionary Girl Utena is queer. For this reason, it is extremely difficult to offer a comprehensive reading of the whole show. And precisely because Revolutionary Girl Utena exudes so much queerness, prime queer theorist Sedgwick will inform my reading. In a not totally dissimilar manner to Utena's heroic battles, Sedgwick also performs a hero-like role of champion of the effeminate boys. In her classic essay, Sedgwick not only makes the institutionalized homophobia that targets effeminate boys accountable; she also names and marks specific homophobic agents: "Dr. Louis W. Sullivan, Secretary of the Department of Health and Human Services" (1991: 18), the American Psychiatric Association, the psychoanalytically informed theorists Richard C. Friedman and Richard Green, and Yale University Press for publishing in book format their deeply homophobic accounts (19). In addition, Sedgwick attempts to add nuance to the stories of (some) mothers, who are vilified figures in the psychological accounts she surveys. Sedgwick never claims for herself the position of mother; however, even the framing of the question in the title of her essay "how to bring your kids up gay", or in a slightly different iteration "how to help your kids turn out gay" (23), presupposes an adult parent-like figure as the addressee of the question. Unlike the parental adult audience that Sedgwick's essay imagines for itself, Revolutionary Girl Utena's intended audience was, as is the case with most shoujo anime and manga, female-identified teenagers and young women. ${ }^{1}$ Part of my

\footnotetext{
${ }^{1}$ As Jennifer S. Prough argues, "Shōjo manga is for girls. [...] In fact, in the manga industry, titles, magazines, and even publishing house divisions are all organized by gender. Thus, gender is at the heart of shōjo manga" (2011: 1).
} 
contention is that Revolutionary Girl Utena allows audiences to think of enabling modalities of queer childhoods in a wider gender spectrum than Sedgwick's essay.

In this article, I offer a close reading of one episode of Revolutionary Girl Utena, episode seven, called "Unfulfilled Juri". ${ }^{2}$ My reading will focus on one of the queer female characters that the show cultivates, the anime lesbian. The figure of the anime lesbian is embodied by the main character of this episode (who is just a supporting character in the show), Juri Arisugawa. Juri is the only female member of the elite council and a duelist, and importantly, her name sounds very similar to "yuri", a manga/anime genre that focuses on lesbian relationships. Among the generous spread of queerness in the characters of Utena, Juri is the most undeniably lesbian character of the show. Ultimately, a close reading of the queer femininities and female masculinities presented in this episode illustrates some of the figures that are left out of Sedgwick's canonical essay. And, at the same time, my own reading of the episode is deeply inspired by Sedgwick's way of looking at effeminate boys, an approach that doesn't have to be restricted to effeminate boys and that may be expanded to recognize (and be responsive to) other young queer and trans genders and sexualities.

The meagerness of lesbianism in Sedgwick's essay is worth exploring. In the first two paragraphs of the essay, Sedgwick speaks of "gay and lesbian youth" and "young gay and lesbians" (1991: 18). By the third paragraph, Sedgwick drops the lesbian references to mostly mobilize the seemingly gender neutral "gay" in the rest of the essay. A non-exhaustive list of her deployment of "gay" includes: "visibly gay" (18), "gay men” (19), "gay movement”, "gay thought” (20), "gay acceptance”, "gay people" (23), "gay development", "gay-loving people" (25), "gay-eradicating momentum", "gay producing circumstance", "gay generation", "gay bodies" (26). Sedgwick justifies her relative silence on lesbian kids by stating that "the monographic literature on the subject [children brought under the Diagnostic and Statistical Manual III] is, to begin with, as far as I can tell exclusively about boys" (19). If we take her at her word, Sedgwick's apparent silence on queer female and trans children can be read as her tentative, contextually-bound, and strategic response to a set of fields that obsessively target and dissect effeminate boys. It cannot be any other way for Sedgwick, an author who cultivated queer theories that treasure transitivity "across genders, across sexualities, across genres, across 'perversions"” (2011: 188).

Unlike Sedgwick's essay on effeminate boys, Revolutionary Girl Utena does dwell on young female queer genders and sexualities. Even before the episode properly begins, the ninety-second opening song sequence, "Rondo-Revolution",

\footnotetext{
${ }^{2}$ My reading is based on the Revolutionary Girl Utena Limited Edition DVD Box Set licensed by Nozomi Entertainment (2011).
}

214

Lectora, 27 (2021): 211-226. ISSN: 1136-5781 D.O.I.: 10.1344/Lectora2021.27.10 
performed by Masami Okui, frames Utena and Anthy as the main romantic pairing of the TV show. Following the conventions of TV anime openings, a cast of duelists in glamorous battling uniforms and poses is then introduced. Juri's brief sequence in the opening offers a quick movement from close-up, to medium shot, and finally to a long shot. Unlike the other duelists, who in their respective shots struggle in the middle of a duel, Juri effortlessly handles the sword and, instead of fighting, seems to be dancing. Unlike Utena and Anthy, who are framed as potential lesbian lovers, nothing in Juri's apparition in the opening sequence hints at the possibility that she is actually the lesbian character of the show. Perhaps, here, Utena is inviting its audience to think of how doubly invisible femme lesbians can be rendered.

The episode begins with a shot of Juri, who only offers us here her profile. Simultaneously, we can hear Juri's voiceover saying in a melancholic tone, "[y]ou see, you just have to give up. Because there really are no such things as miracles". Juri's voice and the image of her profile are not in synch. Perhaps this references the fact that the voice of Juri we hear is from a different (future) time than the images we see. Juri is seated and a female student tenderly covers Juri's eyes with her hands. This female student, Shiori Takatsuki, we will soon discover is Juri's impossible object of desire, the evidence of her (somewhat tragic) lesbianism. The episode moves from the melancholic images of Juri's past in which she was caressed by her object of desire to her present as captain of the school's fencing team. Miki Kaoru, another duelist, compliments her abilities with the sword, saying to Juri, "[n]o one can beat you". However, queer spectators may assume that Shiori, the impossible object of lesbian desire, will be the one to beat Juri.

The title of the episode is introduced as "Unfulfilled Juri". "Unfulfilled" references incompletion, to not having reached full (adult) potential of oneself or one's desires. Coincidentally, "unfulfilled" could be an adjective to describe how the corpus of psychological and psychoanalytic theories that Sedgwick incisively criticizes labels effeminate boys. However, Juri's unfulfilled character seems less obvious, especially because she is portrayed as possessing so many virtues: beauty, power, intelligence, and strength. In Heather Love's terms, Juri's beauty makes her fit a longstanding trope of a lesbian as "at once the sexiest possible woman and at the same time an abject and unwanted creature" (2004: 123). Juri's beauty is conventionally feminine and rivals the beauty of the main protagonist, Utena. Actually, in this episode Utena at one point says to Juri, "[y]ou really look like a super model". Juri's beauty does not go unnoticed, not even by the sometimes-oblivious Utena. The conventionally feminine and gallant beauty of Juri echoes the physical appearance of the tragic protagonist of The Rose of Versailles (Riyoko Ikeda, 1972), Oscar Francois, another gender outlaw. Juri is beautiful but is also someone who inspires fear. The episode very openly displays the Vice-Principal of the school as 
somewhat fearful of Juri and her power. It wouldn't be a stretch to suspect that an essential part of what makes Juri a scary "personality" is her lesbianism. Her lesbianism, in this sense, is figured as an abject threat, which one shouldn't mess with. Utena confirms all this in a conversation with Juri:

We've heard all about you, even in the junior high class. The fencing team captain and great student council member who can get rid of even a teacher with one glance. But they say you're trouble, and that people who know your hidden face wouldn't get within ten meters of you.

Another paradox has to do with visibility; Juri's lesbianism is supposed to be a secret and yet everyone knows that she has a "hidden face", or a secret that she protects.

In their dialogue, Utena and Juri portray two different possibilities of embodying queerness. Paraphrasing Sedgwick's famous axiom, queer women "are different from each other" (2008: 23). Whereas Utena is free-spirited, naif and kind, Juri has a terrifying glance that scares people (or freezes people, like a Medusa). Utena, with her straightforward attitude, asks her directly: "You're after the Rose Bride, doesn't it?" [sic]. This question -in the relaxed voice and bodily gestures of Utena - is not a complaint from a jealous lover over the possession of a female body, Anthy. Utena's voice, while raising that question, sounds innocently childish. A shot that frames the "terrifying glance" of Juri is far from signifying any desiring drive toward Anthy. In her response, and in a seemingly inconsequential manner, Juri states that all the duelists are after the Rose Bride, because whoever is engaged to her will gain the power of embodying miracles, or what in the show is named the power to revolutionize the world. In their dialogue, Utena starts to playfully flex her legs (as if preparing to workout), whereas Juri remains in the same immobile and stiff pose. Utena wonders loudly if she could use that miraculous power to pass all her school exams. Juri continues with the same stiff pose and glance, without being able to look directly at Utena's face. After the spectators get a glimpse of the shadowy figure of Shiori in a flashback, Juri turns her head and glance to face Utena, and she informs her in a confident tone that she is not interested in Anthy. Juri justifies her disinterest in Anthy by making reference to her belief in the inexistence of miracles and their power. The spectators once again hear the voice of Shiori, the object of lesbian desire, affirming the existence of miracles. Shiori's voiceover in this scene questions the certainty of Juri's declaration. That voice comes from Juri's past to remind her that she once treasured the utopian possibilities of miracles. The exchange between Utena and Juri is interrupted by a call informing Utena that her presence is being solicited by a schoolteacher. Utena seems to believe that she and Juri are on the same page in reference to their incredulity about the illogic series of duels over Anthy's body.

216

Lectora, 27 (2021): 211-226. ISSN: 1136-5781 D.O.I.: 10.1344/Lectora2021.27.10 
Immediately after Utena leaves the frame, Anthy appears on it, carrying an orange rose in her right hand. Anthy kindly offers the orange rose to Juri, who slaps Anthy's face in response. At this point in the narrative, Juri is not a likable character; one is not supposed to identify with her. In fact, it is not clear that the anime lesbian's politics are progressive at all. ${ }^{3}$ Moreover, it may be relevant to note that Anthy, the Rose Bride, is the only feminine character of the show marked as brown; her dark skin contrasts with the light skin tonalities of (almost) all the other characters. (In fact, the other two brown characters in Utena, Akio Ohtory and Mamiya Chida, are directly related to Anthy. Akio, we will discover in later episodes, is Anthy's older brother, and Mamiya is a trans alter-ego of Anthy). As noted, Juri doesn't hesitate to exercise shameless violence on Anthy's face and, in fact, this obscene exercise of violence links Juri with an obnoxious male character, Kyouichi Saionji, that in the first two episodes of the series duels with Utena over the possession of Anthy's body.

In the sexual longings of the previous two male duelists, Saionji and Miki, one could argue, paraphrasing Priya Jaikumar, that "the dark figure's difference is disavowed by fetishizing or overvaluing [her] beauty” (2006: 159). But Juri doesn't traffic in the same fetishizing of Anthy's body. However, Juri's violent reaction against Anthy has implications in terms of racial politics. Kotani characterizes Anthy as a "slave princess" (2006: 165), perhaps marking Anthy as black. ${ }^{4}$ During the duels, Anthy performs the role of vessel onto which the duelists project their desires; the duelists use Anthy's blackness as triggering this traffic of desires. Unlike the previous two duelists, Juri doesn't sexually desire Anthy. Nonetheless, it is difficult not to notice that in her delicate demeanor and appearance, including the soft shade of purple of her hair, Shiori looks similar to Anthy. So, when Juri slaps Anthy, perhaps we are witnessing an aggression that has as an intended target a lesbian object of desire who doesn't love back. If this is the case, Anthy's body would be a topography in which Juri stages her revenge against Shiori.

\footnotetext{
${ }^{3}$ Juri is the character most clearly marked as lesbian. However, that doesn't translate necessarily to progressive racial politics. For instance, Juri's violence toward Anthy aligns her with many of the other characters of the show that traffic in anti-black and anti-brown hatred. In all fairness, there is nothing essentially anti-racist in being a lesbian.

${ }^{4}$ Anthy is the most ambiguous character of Utena. Importantly, Anthy's race contributes to her character's opacity. As Kotani suggests, Anthy can be read as black. At the same time, Anthy wears a bindi, potentially marking her as South Asian. These identity markers (black, South Asian) are not mutually exclusive. Anthy may be read as black, brown, and/or South Asian by different international and regional audiences. There is also the possibility that in relation to Anthy's race the point is not to know.
} 
In Utena, a rose (particularly on the chest of a duelist) stands for a duelist's more radical (and in most cases hidden) desires. In Juri's refusal of the orange rose, audiences could initially think that she may be partially disavowing her lesbian desire for Shiori. But this is not a simple homophobic disavowal. In a flashback, Shiori kindly offers an orange rose to Juri, whom we may assume accepts the gift. When Juri violently declines Anthy's orange rose, what the former is rejecting is an exchange economy that constructs Shiori and Anthy as interchangeable objects. For Juri, Shiori is irreplaceable. Juri's violence against Anthy also signals the former as perceptive, as Juri seems to know that Anthy is not a stereotypical victim. If Anthy is a victim, her victimhood is willful. Anthy is a character that is part of the "complot" that designs the turbulent affective scenarios that trigger the duels, a "complot" that has Anthy's brother and lover, Akio, as the ultimate master. It is not a coincidence that the rose that Anthy carries is neither white nor pink. Revolutionary Girl Utena matches colors with characters, especially their hair. When Utena duels, she carries on her chest a white rose, while the orange rose seems to have been destined for Juri from the very beginning. She intuits that Anthy may be momentarily trying to pass as Shiori, but Juri doesn't allow herself to be confused by Anthy's tricks.

Juri refuses to be played by Anthy, and by Utena's narrative plot, and rejects becoming a character that has a deep longing to conquer Anthy. Paradoxically, the only character marked as exclusively lesbian is unable to desire the female character that the TV series portrays as the most desirable one. Juri's refusal to take part in the traffic in women may be the most revolutionary side of her lesbianism. If that is the case, maybe Juri's not wanting to have Anthy is related to Juri not having Shiori. Hélène Cixous provocatively asserts that "[l]ove is 'not having'. One can love only on condition of not having what one loves" (1990: 112). "Not having what one loves" can be the caption that frames Juri's unrequited lesbian love. Cixous sees a radical potential for newer and queerer forms of love in that "not having". Unlike a masculine and scopophilic desire to possess, Juri seems to be a living testimony of the pains and joys of the desire to not possess. Juri's lesbian love story can also be read as a model of loving while not having, of loving in queer shapes that defy heteronormative scripts (even from within them).

In the subsequent sequence, Touga Kiryuu, president of the student council, and Miki discuss with Juri some of the arrangements made by Akio, who at this point of the TV series is known only as "The End of the World", the duels that will follow. Touga, playing the role of the male analyst, suggests that Juri actually doesn't want to disprove miracles, and Miki questions why Juri would want to duel, not because of her lack of talent with the sword, but for her lack of motive. As Touga practices his knife-throwing skills, he raises questions about Juri, as if his inquiries are supposed to wound her. He again asserts that Juri very likely may 
want to make "her hidden feelings known". The episode stresses that the anime lesbian Juri is a character who mainly carries the burden of secrecy. But it goes without saying that the secrecy of Juri's feelings is actually public knowledge, as Touga's masculine voice doesn't hesitate to overstate. Miki concludes this dialogue with a seemingly tautological question: "Miss Juri, you're in love with someone?". Juri continues giving both men her back. A queer spectator may wonder if Juri's refusal to give her face to these two men is a repudiation of the contract that makes a spectacle of the anime lesbian's sorrows. Unlike Sedgwick's effeminate boys who lack the capacity to speak back to the homophobic accounts of their male analysts, Juri refuses to be part of an inquisition conducted by two amateurish male analysts. This exchange ends with a shot of Juri facing straight to the audience, undisturbed by the knives that pass very near her. Indeed, Juri declines to answer to Miki and Touga, but not to the spectators of Utena. The sequence ends with Juri's silent declaration in an inner voice register: "Yes... I was in love". Juri's love declaration is paired with a close-up of Shiori. A queer spectator is reassured at this point that Juri's elusive object of desire is another girl.

Another flashback begins with a closeup of Shiori's empty gaze. She is the only attendant at a fencing duel. The character who loses the match is a young man whose first appearance is framed by white roses. He says, "I surrender. You've beaten me". The other duelist takes off her fencing mask, and unsurprisingly, it is Juri, who is framed as surrounded by orange roses. The male character says directly to Juri, while we witness her joyful and triumphal smile, "[y]ou are as good as anyone on the high school boys' team, Juri”. Of course, at this point of the episode we know that this is a blatant lie: Juri is not as good as those boys, she is way better. So far in the show, Juri's abilities with the sword are unmatched. Juri answers such a diatribe disguised as a compliment with a delicate " $t \mathrm{t}]$ hank you". Shiori carries an orange rose, and offers it to Juri, while framed by orange roses. Only Shiori and Juri are framed by orange roses; the male character is not, and he remains nameless during the whole episode and show. Besides this episode, he will never appear again on the TV series. The fact that, at this point, neither the young man nor Shiori are named reifies their bond somewhat. However, in episode seventeen, Shiori will be Utena's main rival in another fencing duel. Shiori remaining nameless in episode seven highlights the difficulty of fixing and naming with certainty (some) queer female desires and passions. Unlike Juri, who has a proper name that marks her as exclusively lesbian, Shiori seems to escape an economy of names that arrest and immobilize bodies and desires. The uneven weight that Juri's and Shiori's names carry perhaps plays a role in why Shiori's invitation to "believe in miracles" feels a bit injurious. To begin with, Juri doesn't want "miracles" in the plural. She is stuck in her desire for a singular miracle, her romantic longing for Shiori. Shiori offers an orange rose to Juri while proclaiming, "[b]elieve in miracles 
and they will know your feelings". Juri accepts the orange rose as a gift, as we can see in an image that frames the triad with Juri, holding the orange rose at the center while gazing straight ahead. It would be easy to assume that in Juri's acceptance of the rose she is endorsing at face value her belief in miracles. However, Juri's voiceover disturbs that presumption. "But I knew it even then, knew that this love could never go anywhere" is the dictum of the unfulfilled anime lesbian's pathos in the voice of Juri herself, and what disentangles her from Shiori.

The docility of the past version of Juri contrasts with the severity of her present walk, gestures, and voice. Now in her own bedroom, Juri looks at a photo frame that contains a schoolbook photograph. The photo has several seemingly interchangeable bodies that lack any particular and legible features. These images are synched with Shiori's voiceover reading a letter penned to Juri: "I know he didn't say it, but I think you were always first in his thoughts, Juri". A frontal shot of the nameless young man again appears on the screen. Perhaps Juri was first in his thoughts, but a queer spectator knows that Juri didn't have any interest in him. Shiori, in voiceover mode, asserts, "[e]ven so, I wanted to take him from you". A heteronormative viewer may desire to project a narrative of business as usual, in which a bad girl and a good girl dispute over a boy's favors. But Revolutionary Girl Utena disappoints all those normative expectations. Shiori continues: "Even if it meant taking everything from you... I just wanted him to know my feelings". This statement is undermined by another flashback that takes us to the time of the actual shot of the school photograph. Shiori turns her head in the direction of the nameless male character in order to address him, "[d]id you know? There's someone Juri's in love with. But it isn't you". And that is the exact moment in which the photo is taken. Once again, Shiori's voiceover reads the letter, "[ $t$ ]hat's why I took him from you. And I have no regrets about it". Shiori took something from Juri, but actually, she doesn't know what. Here it becomes obvious that the nameless young man functions as a sort of vessel. He is used as a connection between two women whose passions resonate and clash in queer ways.

Juri, Shiori, and the nameless young man form a female homosocial triangle. Precisely, Sedgwick, in her landmark Between Men: English Literature and Male Homosocial Desire (1985), theorizes the intricacies of triangular forms of desire. Sedgwick coins the notion of "male homosocial desire" to name a continuum of "men-loving-men" and "men-promoting-the-interests-of-men" (2016: 3) at the heart of heteronormativity. Sedgwick famously claims that

[René] Girard seems to see the bond between rivals in an erotic triangle as being even stronger [...] than anything in the bond between either of the lovers and the beloved. And [...] the triangles Girard traces are most 
often those in which two males are rivals for a female; it is the bond between males that he most assiduously uncovers. (2016: 21)

Episode seven of Utena offers a female version of such a triangular form of desire. Indeed, the bonds between the same-sex characters (Juri and Shiori) are stronger than either of them has with the nameless young man. In Sedgwick's theorization male homosocial desire, rather than a different name for homosexuality, is actually a modality of "male heterosexual desire, in the form of a desire to consolidate partnership with authoritative males in and through the bodies of females" (38). This is where the equivalence between the triangles of Sedgwick's male homosocial desire and Utena's female homosocial desire fall short. Instead of enforcing normative heterosexuality, Revolutionary Girl Utena openly stages Shiori and Juri as intrinsic parts of a triangular scenario of desire that demands an articulated play between assertions, disavowals, and displacements of queer female desire. In this female homosocial triangle, the apparent disavowal of a female queer bond actually propagates queerness to new peaks and heights. This gender imbalance corroborates Judith Mayne's claim that "there may be no easy way to substitute a female-male-female erotic triangle for the male-female-male one that Sedgwick describes" (2000: 187).

Sedgwick's male-female-male erotic triangle at a certain level presupposes that the two male poles occupy symmetrical positionalities. Even if not in an obvious manner, Sedgwick's essay on the effeminate boys complicates this understanding of triangular relationality. In this case, we have the figures of a homophobic male analyst and mother using the small body of the effeminate boy as a vessel to traffic in the ideological tenets of heteronormativity. However, it is clear that this triangular exchange only favors one of its elements, the homophobic male analyst. In the psychological accounts Sedgwick reads critically, the figure of the mother is vilified and blamed for turning her child gay. Actually, this triangle has two bodyvessels, the effeminate boy and the mother. In any case, what both Sedgwickian theorizations of triangular desire share is an unrelenting disruption of an idyllic notion of a heterosexual dyad. As Judith Butler remarks, "[Sedgwick's] early work on triangularity exposed [...] how the dyad is never quite as closed as it may appear" (2019: 68). Coincidentally, in Utena's episode seven, the triangular relation between Juri, Shiori, and the nameless young man complicates any desire for ending the story with such a heterosexual dyad.

Still in flashback mode, we see the same trio with Juri in the middle. It seems almost as if a red thread cuts Juri's face. The red thread, or the thread that opens red wounds in Juri, is a sort of communication device that connects Shiori and the nameless man. So, here, Juri performs the role of vessel. This makes explicit that in triangles of homosocial desire, even people who share a gender identification 
don't necessarily inhabit homogenous positionalities. We can see Juri's profile in her feminine school uniform. Shiori repeats her plea to believe in miracles, while at the same time she covers Juri's eyes. Here, Shiori and Juri certainly occupy hierarchical positions; it is Shiori who covers Juri's field of vision, and it is Juri who renounces the concretion of her erotic desires. Nevertheless, in this triangle hierarchies are not as fixed as in Sedgwick's male homosocial erotic triangle (that clearly differentiates between male subjects and female vessels/objects). While Shiori covers Juri's eyes, she kisses the nameless man. This gesture may be read as Shiori's generous effort to blind Juri to the most explicit and clichéd imagery of the heterosexual exchange. Paradoxically, Shiori also enacts a form of blindness herself, an unwillingness to see the obvious, that she is Juri's object of lust.

The affective intensity of those flashbacks demands so much from Juri that she takes a shower. The sound of the shower perhaps echoes the liquidity of Juri's tears. Her beautiful long hair covers her face; spectators may intuit Juri's tears, but the show holds the anime lesbian's tears from the field of the visible (at least in this episode). After taking a shower, Juri gives her back to the audience and begins to dress with a feminine robe. We can hear her inner voice now in synch with a shot of a letter. We now know with certainty that the previous lines pronounced by Shiori were excerpts from that letter. We can hear Juri's tentative response to Shiori's letter: "Thank you for the note. You seem to be doing well. As I read the words in it, one by one... I realize my feelings haven't lessened as time has passed". Juri doesn't hide the perseverance of her passion. Actually, she implies that she is invested in "reading word by word" the memories of such a passionate bond.

Further evidence of Juri's passionate bond can be found in her pendant. We can see Juri lifting the necklace (that was on top of Shiori's letter), and then putting the pendant around her neck. We hear Juri's inner voice: "No matter what happened, the three of us were truly happy back then. However, when I see your faces now, shining with happiness... it makes me feel nostalgic. It makes me feel envious". And then Juri's voice is interrupted by the abrupt sound of a picture frame knocking the floor. It is Juri who throws that school picture, and who interrupts her own declaration. This sequence makes clear that the pendant has an intimate material relation to the drama that Juri suffers within a heteronormative structure. It is almost as if by touching the pendant, Juri cannot continue lying to Shiori. Clearly, for Juri what happened in the past mattered, matters, and will continue to matter. The pendant suggests the importance of the tactile dimension of memory, especially of those memories of unrequited love. The sequence closes with a shot of Juri's school picture with her past feminine demeanor and her eyes closed, suggesting that visuality is not always the tragic lesbian's favored sense. Juri can be rendered the lesbian character of Revolutionary Girl Utena only in a sexual imaginary that favors visuality in detriment to other senses. Juri's plea for tactility, via 
her pendant, hints at mechanisms of escape from heteronormative triangular forms of desire. It is through her tactile appeal to memory that Juri begins to let loose her lesbian passions and sorrows.

The second half of the episode begins with Utena walking home at night. We are able to identify Juri's statuesque figure among shots of statues. The statuesque beauty that Utena and Juri share stresses once again their differences. Unlike Juri, who cannot confess her attraction to Shiori, Utena doesn't have a problem in sharing her admiration for Juri's beauty, especially when Juri wears a white robe fashionable enough that it can pass as a fancy dress. In a colloquial tone, Utena says to Juri:

You're not wearing your school uniform. So I couldn't tell who you were at first. You really look like a super model. You look pretty cool in your uniform, but I'll bet everyone would be really surprised if they saw you in such a girly outfit.

From their dialogue, it is clear that Revolutionary Girl Utena doesn't offer its viewer a single model of queer female subjectivity. In fact, in this TV show queer femininity isn't singular, but multiple. Juri asks Utena about her choice of always wearing a male uniform: "I see you keep your uniform even at night. Why do you always wear a boy's uniform?". Utena explains that she does it because of a promise she made to a prince in her childhood. At first Juri seems curious about Utena's desires and gender. At one point, Utena states that she was so impressed by the prince that she wanted to be like him. In contrast, there is not a single moment in the episode in which Juri expresses any desire to embody masculinity. And yet, Juri doesn't display a transphobic attitude toward Utena's queer masculinity. Actually, Juri approaches Utena and caresses her, gazing at her with lust. Utena is receptive to Juri's caresses. And once more, instead of witnessing a "successful" scene of lesbian cruising, the spectators face another lesbian mis-encounter.

Juri takes advantage of their physical proximity to try to take a ring off of Utena's hand. At this point of Utena's plot, the ring stands for a promise of an eventual heterosexual marriage between Utena and a prince. As if agreeing with Sedgwick, who writes that "to cast the narrative in terms of a 'Prince' and a 'Princess,' is both a conventional, transparent fairytale device, and a tendentious reading of history" (2016: 124), the TV series will eventually disturb such a normative convention, because ultimately the ring is the only remnant of a promise that Utena actually made to Anthy as a little girl. In this episode, Utena's ring fits a heteronormative narrative, whereas that same heteronormative framework turns Juri's pendant into a lesbian fetish and her queer desires into the realm of the unreal. Juri is perfectly cognizant of how unfair the distribution of futurity is between 
her own pendant and Utena's ring. During this heated exchange, we glimpse an intensity in Juri's eyes that we haven't seen before. The feelings in Juri's eyes and voice are the most intense when she announces a duel challenge to Utena: "Then show me the miracle you talked about! I'll force the proof from you with my sword!". The potency of Juri's eyes and voice, thanks to the fierce performance of voice actress Kotono Mitsuishi, fills its viewer with queer feelings, defying the apparent affective limitations of cel animation.

Once the duel between Utena and Juri is set, we see Utena's grandiose entry into the duel arena. As part of this sequence (that we encounter six of the seven times Utena duels in the first twelve episodes of the show), we see a spectacular spiral staircase. According to Mary Ann Doane, "the staircase is traditionally the locus of specularization of the woman. It is on the stairway, that she is displayed as spectacle for the male gaze" (1987: 136). This sequence is self-consciously displaying the centrality of Utena's body, but it works as a campy parody of conventional Western displays of feminine beauty. Revolutionary Girl Utena doesn't intend to satisfy a normative male gaze. In this episode, Utena and Juri's duel is not a preamble to a heterosexual(ized) bond. If anything, the spectacle of the anime lesbian trials is displayed for a queer gaze, a viewing position not prone to conquer nor to freeze desire.

The reason for the duel is that Juri wants to disprove the force of miracles, a promise that Utena and Anthy's bond, through the imaginary mediation of a prince, seems to embody. This duel has its own song. The lyrics of the song include keywords such as "apocalyptic", "androgynous", "Thanatos", and "the pleasure principle", stressing the investment of this episode in queerness. The duel is the affective climax of the episode. Unlike the previous battles in which Utena beat her opponents with the miraculous descension of the spirit of her prince onto her body, in this duel Utena's sword abilities are no match for Juri's power, not even with the help of the prince. Juri is able to render Utena armless throwing her sword into the air. However, miraculously, Utena's sword descends from the sky (like the prince himself) to extricate the orange rose from Juri's chest. There is a paradox in the fact that a hypothetical victory by Juri would reinforce the subjective position that the last sentence in the lyrics of the duel song attributes to her: "Inside I'm hollow". Juri's defeat is a sign that her love life may be "unfulfilled", but it is far from empty. The queer affects that surround Juri are rich, and those affects invite Utena's audience to dwell on the exuberance of queer affective experiences.

The theme of Juri's (very public) hidden love arises once more at the end. After the loss, Anthy says to Juri, "[m] ay they know your true feelings, one day". It goes without saying that Juri refuses Anthy's sudden kindness. And outside of the duel arena, Touga asks Juri if she wants "to let them finally know your hidden feelings". Working as a belated punch line, the final sequence of the episode shows Juri 
seated under a tree, with melancholic music in the background. Juri seems absorbed in looking at her pendant. We "discover" at this final point that within the pendant there is a picture of Shiori. For spectators less attuned to queerness, this final revelation is supposed to work as a surprise. For spectators that resonate with queerness, Juri's pendant is an object that mobilizes simultaneously at least two senses: touch and vision. The vision that Juri's pendant alludes to does not have to do with an investment in the present. It has even less to do with a refusal to accept that one doesn't usually end up on the winning side of desire's economy. The kind of vision that Juri represents concerns the past, and the many virtualities that lie dormant in the past, and that can be activated and radicalized in the future. Shiori's image in Juri's pendant is cut from a photograph in which Juri stands with her eyes closed. Juri's disavowal of normative vision hints at Laura U. Marks' assertion that "it is hard to look closely at a lover's skin with optical vision" (2000: 163). For Marks, optical vision is obsessed with an endless search for visual plenitude, via a deployment of disembodied abstractions. Juri's look at Shiori's skin echoes Marks' notion of haptic vision, "a sensuous response [that] may be elicited without abstraction [...] [and that] does not require an initial separation between perceiver and object" (164). When Juri poses with her closed eyes she is reliving the memory of Shiori's fingers delicately covering her eyes. In other words, she is calling to the present her miracle, the scent and feeling of Shiori's skin. In this way, Juri "come[s] to the surface of [her] self [...] losing [her] self in the intensified relation with an other that cannot be possessed" (184).

In the end, Juri's desire for a miracle survives the episode's tribulations. Coincidentally, survival is a key concern in Sedgwick's aforementioned essay. The psychoanalytic and psychological accounts that Sedgwick reads are perplexed by the survival of the effeminate boys, by the "residue of mystery" (1991: 22) attached to their future resilience. Sedgwick goes as far as to hypothesize that the effeminate boys' "mysterious skills of survival, filiation, and resistance could derive from a secure identification with the resource-richness of a mother" (23). At this point, Sedgwick undoes the triangle, throws into the air the male analyst, and favors the dyad of the effeminate boy and an antihomophobic mother. In a similar manner, the ending of episode seven crushes the female homosocial triangle in favor of a longing for a (non-closed) female dyad, and it cultivates this longing as miraculous. In "Queer and Now", included in her volume Tendencies, Sedgwick professes that "I look at my adult friends and colleagues doing lesbian and gay work, and I feel that the survival of each one is a miracle" (1993: 1). Thinking of queer survival - particularly of former queer kids - as miraculous is tantamount to Utena's own desires to embody prince-like masculinity, and allows us to see in Juri's defeat the beginning of something else. To borrow Marks's words, Juri's "haptic visuality implies making oneself vulnerable to the image" (2000: 185), and, I would add, to the 
joys and sorrows of queer love. This is one of the reasons why for some queer spectators of Revolutionary Girl Utena, and of Juri's arc in particular, the TV series works as a modality of queer affective education. There is something simultaneously modest and grandiose going on here. In a word, Revolutionary Girl Utena offers a glimpse of how inextinguishably vast queerness feels.

\section{WORKS CITED}

Butler, Judith (2019), "Proust at the End”, Reading Sedgwick, Lauren Berlant (ed.), Durham, Duke UP: 63-71.

Cixous, Hélène (1990), Reading with Clarice Lispector, Minneapolis, University of Minnesota Press.

Doane, Mary Ann (1987), The Desire to Desire: The Woman's Film of the 1940s, Bloomington, Indiana UP.

Ikuhara, Kunihiko (dir.) (1997), Shoujo Kakumei Utena, J. C. Staff, eps. 1-39.

Jaikumar, Priya (2006), Cinema at the End of Empire: A Politics of Transition in Britain and India, Durham, Duke UP.

Kotani, Mari (2006), "Metamorphosis of the Japanese Girl: The Girl, The HyperGirl, and the Battling Beauty", Mechademia, 1: 162-169.

Love, Heather (2004), "Spectacular Failure: The Figure of the Lesbian in Mulholland Drive", New Literary History, 35: 117-132.

Marks, Laura U. (2000), The Skin of the Film: Intercultural Cinema, Embodiment, and the Senses, Durham, Duke UP.

Mayne, Judith (2000), Framed: Lesbians, Feminists, and Media Culture, Minneapolis, University of Minnesota Press.

Prough, Jennifer S. (2011), Straight from the Heart: Gender, Intimacy, and the Cultural Production of Shōjo Manga, Honolulu, University of Hawaii Press.

Saito, Chiho (2020), Revolutionary Girl Utena: After the Revolution, San Francisco, Viz Media.

Sedgwick, Eve Kosofsky (1991), "How to Bring Your Kids Up Gay”, Social Text, 29: 18-27.

-(1993), Tendencies, Durham, Duke UP.

-(2008), Epistemology of the Closet, Berkeley, University of California Press.

-(2011), The Weather in Proust, Jonathan Goldberg (ed.), Durham, Duke UP.

-(2016), Between Men: English Literature and Male Homosocial Desire, New York, Columbia UP. [1985]

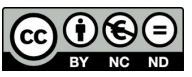

226

Lectora, 27 (2021): 211-226. ISSN: 1136-5781 D.O.I.: 10.1344/Lectora2021.27.10 